\title{
Edubox Utilization as Tool For Evaluation of Learning Outcomes Social Studies
}

\author{
Inggar Carissa Ambarwati ${ }^{1}$, Kokom Komalasari ${ }^{2}$, Ridwan Effendi ${ }^{3}$ \\ ${ }^{1}$ SMP Yayasan Atikan Sunda, Bandung \\ ${ }^{2,3}$ Social Studies of Education Study Program, Faculty of Social Sciences Education, \\ Universitas Pendidikan Indonesia, Bandung, Indonesia
}

\begin{abstract}
This research discusses about E-Learning, which is needed to balanced Education in this modern era. There is a difference in the implementation of E-Learning in every school, what the researchers found is the evaluation system to get the results of learning the value of knowledge that is done online by using an application called Edubox. This research aimed :(1) To know the student's response to Edubox utilization as an evaluation tool in SMP Negeri 10 Bandung. (2) To know effective IPS learning outcomes of students after using Edubox class VII SMP Negeri 10 Bandung. (3) To Know the results of the cognitive Social Studies learning of students after using Edubox in class VII SMP Negeri 10 Bandung. This research used qualitative descriptive study methods. The participant of this research is 7 random students in every class, Social Studies teachers and vice-principal as the facilities and infrastructures in the field of management Edubox. The Data collecties by interviews, observations, and documentation, while analyzing data using data reduction, data presentation, data verification. The finding shows that 1) the response of the learner, educators, schools on the existence of Edubox brought a positive impact so that the evaluation can be implemented easily. 2) Edubox presence provide change to students in affective learning outcomes such as attitudes, interests and better self-concepts. 3) Edubox can make the learning results in the form of the knowledge value of the learners increased from the previous results. Therefore, I used Edubox as Social Studied learning outcome tool.
\end{abstract}

Keywords: E-Learning, Edubox, Evaluation, Learning Outcomes

Correspondence. inggarcarissa4@gmail.com

Article History. Received January 2019, Received in revised March 2019, Accepted June 2019

O2019. International Journal Pedagogy of Social Studies. Department of Social Studies Education

\section{INTRODUCTION}

Education has a very important role in the progress of a nation. Education is also a need that must be met by every individual. Through education will create the quality of human beings and have good character. In Indonesia, education has changed from time to time, both in terms of curriculum, learning methods, and evaluation of learning to obtain learning outcomes.

Based on the latest curriculum objectives in Indonesia, which talks about the results of learning evaluations that currently do not only look at aspects of knowledge.

In the curriculum structure, it has been explained that education in Indonesia focuses on learning outcomes on aspects of attitude, knowledge and skills. This is in line with what was conveyed by Nana Sudjana (2009:3) suggesting that student learning outcomes are essentially changes in behavior as a result of learning in a broader sense covering the cognitive, affective, and psychomotor fields. Which the cognitive aspects include students' knowledge and affective aspects include the attitudes of the students themselves. Learning outcomes are the most important part of the learning process because as a determinant of the final results of education carried out by students. According to Muhibbin (2010:128), explaining factors that influence learning outcomes include, internal factors are factors that originate from within students including physiological factors and psychological factors. 
Physiological factors are factors that are related to the physical condition of students during the learning process or when taking a social studies evaluation test. Psychological factors include intelligence, attention, interest, talent, motivation, and readiness of students in learning social studies material. External factors are factors originating from outside students, consisting of the family environment, school environment, and social environment.

Besides the influence, Widoyoko, Eko. (2009:1) explained that learning outcomes are related to measurement, then an assessment will occur towards evaluation using both tests and non-tests. The results of this evaluation test are included in the cognitive domain while non-tests are included in the affective domain and can be seen from the behavior of the interests, selfconcepts, and attitudes of students during the learning process. One form of obtaining learning outcomes is through the process of learning evaluation, the implementation of the evaluation itself in each school must have their differences both conventionally of technology.

On the other hand, what is happening right now about the phenomenon of information and communication technology that is leading to modern developments. By utilizing the existence of a data network on a computer that can be connected to other computers this is referred to as the internet, even the reach of the internet can now be accessed via a Smartphone. The rapid development of information technology can be utilized in all aspects of life and one of them is education.

Of course, this will bring a very big influence on the world of education. With the existence of technology and the internet, the government through the education service provides website pages that can be used as a forum for the learning process. This is one step to improve the quality of education in Indonesia, so the existence of technology provided by the government should be utilized so that education can run in balance with the development of this very rapid era.

The term of the use of internet technology in education which is increasingly popular nowadays is E-Learning, which is a learning model using communication and information technology media, especially the internet. This is following what was revealed by Michael (2013:27) suggesting that E-Learning is learning that is compiled based on the intended use of an electronic or computer system so that it can support a learning process.

Haughey (in Rusman, 2007) based on the development of E-Learning there is the development of internet-based learning systems such as Web courses which are the use of the internet for educational purposes of all forms of material, assignments and other learning activities found on the internet. The statement above explains that the existence of E-Learning can be used as a tool for the implementation of the learning activities process such as final assignment or as an evaluation. This is in line with observations made by researchers at SMP Negeri 10 Bandung on March 4, 2019, SMP Negeri 10 Bandung has a vision to participate in the development of science and technology as a support for the continuation of the learning process to be ready to face the era of globalization.

The vision of schools in the use of technology is applies as an evaluation tool that is applied in SMP Negeri 10 Bandung called the Edubox Website application, which is used to obtain social studies learning outcomes both in the cognitive and affective domains. This Website-based application is provided by the Bandung city government to facilitate students, educators and also the school in carrying out the evaluation process online. Based on preliminary observations researchers at SMP Negeri 10 Bandung found the fact that the existence of Edubox can bring a very big influence for students on social studies learning outcomes.

From the results of preliminary observations it can be seen that cognitive learning outcomes in the form of students' daily test knowledge scores before using Edubox are fairly low, besides that there is a change from the affective domain in the form of attitudes, interests, and self-concepts addressed by students after using Edubox as a tool for evaluating social studies learning. Of course, this condition can be influenced by several factors from the existence of Edubox in SMP Negeri 10 Bandung.

For this reason, the use of Edubox ELearning as an evaluation tool is expected to be a motivation so that students are more enthusiastic and interested in carrying out social studies learning evaluations. Therefore the existence of Edubox makes researchers want to research to look deeply into the use of Edubox which is used for evaluation in obtaining 
cognitive and affective learning outcomes. Therefore, the authors raise the title "Utilization of Edubox as a Social Studies Learning Evaluation Tool".

\section{LITERATURE REVIEW}

\section{1) Social Studies}

According to Sapriya (2009:7) argues that social studies are one of the names of subjects given at the elementary and secondary levels, subjects in History, Geography, Sociology and Economics, and many other social sciences. NCSS (in Sapriya, 2012:5) argues that social studies education or often referred to as Social Studies are: Social studies is the integrated study of social sciences and humanities to promote competent civic, systematic study drawing upon such disciplines as anthropologists, archeology, history, political, science, psychology, religion and sociology, as well as approve content from humanistic mathematics, and natural science.

\section{2) E-Learning}

According to Michael (2013:27) argues that E-Learning is learning that is compiled based on the intended use of an electronic or computer system so that it can support a learning process. Jaya Kumar C. Koran (2002) E-Learning is a teaching and learning process that uses electronic circuits (LAN, WAN, or internet) to convey the contents of learning, interaction, or guidance.

\section{3) Edubox}

According to the Bandung Service System (2017:22), the Bandung Smart School consists of six services including digital classes, media for teaching materials, links to teaching materials, school collaboration with parents and school administration and examinations and assignments in the network. For this reason, the Edubox Own program is included in the Bandung Smart School service launched by the Mayor of Bandung, Ridwan Kamil.

Edubox is a portable server that already contains learning application software that is easily connected to pre-existing computer networks, either wired (LAN) or wireless (WLAN).

\section{4) Learning Outcomes}

According to Nana Sudjana (1999:24) argues that learning outcomes are changes in behavior as it encompasses the cognitive, affective, and psychomotor fields. Meanwhile, according to Purwanto (1997:22) learning outcomes are the results achieved by someone in business learning as stated in the report card. According to Muhibbin (2008:30), it was explained that learning outcomes are the level of student success in learning school subject matter expressed in the form of scores obtained from test results regarding some specific subject matter.

\section{5) Cognitive Learning Outcomes}

According to Bloom (in Sudjana, 2005: 22) suggests that cognitive learning outcomes are related to six aspects such as knowledge, memory, understanding, application, analysis, synthesis and evaluation. And the following explanation: 1) Knowledge, the ability to know factual and remember and store memorization and so on. 2) Understanding, this ability is a level above knowledge, in capturing or interpreting a meaning of the things being studied. 3) Application, the ability to implement new allies in new situations. 4) Analysis, the ability to sort out integrity so that the structure is clear and has a comprehensive understanding. 5) Synthesis, the ability to unite all elements into a more comprehensive form. 6) Evaluation, the ability to make decisions about everything related to values.

\section{6) Affective Domain Learning Outcomes}

As noted by Effendi, Ridwan and Sukmayadi, Vidi (2017) states that effective learning is as follows: It is called affective taxonomy because it is based on the principle of internalization between both behavior and values in an individual. This Internalization is the basic concept for understanding the taxonomy because the more values and attitudes are internalized the more it affects one's behavior.

According to Andersen (in Amirono and Daryanto, 2016:32) explains that the affective domain relates to a domain that is related to attitudes, inters values and appreciation and appreciation as well as the adjustment of social feelings, even in the measurement process the domain is effectively divided into methods 
observation and self-report, by looking at the characteristics of the students themselves.

\section{METHODS}

The research method used in this research is descriptive using a qualitative approach. The design of this study was chosen because the qualitative approach used in this study was intended to obtain information regarding the use of Edubox as an evaluation tool for social studies learning outcomes. While the descriptive method to find out or reveal by describing the situations and conditions that occur during the process of online evaluation.

The participants in this study Social Studies Subject Educators are:

1) One social studies educator who will be involved makes the participant in this study named Mrs. Euis Sumiyati, S.Pd.

2) The Deputy Principal of the Edubox Management Facilities and Infrastructure

Data analysis techniques used are: 1) Data reduction. 2) Data display, 3) Conclusion drawing, Furthermore there is a data validity test through: 1) Triangulation of data, 2) Member Check, 3) Expert-Opinion.

\section{RESULTS AND DISCUSSION}

The results and discussion in this study to describe and see the use of Edubox as an evaluation tool to determine the results of social studies learning in class VII.

Based on the results of data analysis shows that the existence of Edubox has positive impact ector is named Mr. Frama Achmad Farabi, S.E.

3) Students from VII grade VII Bandung Middle School are subject to research of seven people from each class.

With the location of research in SMP Negeri 10 Bandung.

Data collection techniques in this study are the first is observation. The observation is done by researcher to see learning evaluation activities in class regarding to the use of Edubox as an evaluation tool for social studies learning in SMP Negeri 10 Bandung. Secondly, there is interview technique. The researcher conducted an educator in social studies subjects as well as the vice-principal of the Edubox management infrastructure facilities as well as students in class VII of SMP Negeri 10 Bandung. Third, the study of documentation in this study the documents used are documents relating to the use and implementation of evaluations through Edubox in SMP Negeri 10 Bandung.

on students both in the cognitive and affective domains. The results of the study can be seen in the discussion below.

\section{a. Response of Edubox Utilization as Social Science Evaluation Tool at SMP Negeri 10 Bandung}

Based on the results of the data that has been through the process of triangulation, it can be concluded that the existence of Edubox in SMP Negeri 10 Bandung has a very good impact on the process of evaluating social studies learning. The results revealed by the following triangulation table:

Table 1. Response of Edubox Utilization as Social Science Evaluation Tool at SMP Negeri 10 Bandung

\begin{tabular}{|c|c|c|}
\hline $\begin{array}{l}\text { Grade VII students of SMP } \\
\text { Negeri } 10 \text { Bandung }\end{array}$ & Social Studies Educator & $\begin{array}{c}\text { Deputy head of school facilities and } \\
\text { infrastructure in the field of } \\
\text { management of Edubox }\end{array}$ \\
\hline $\begin{array}{l}\text { active appearance encourages } \\
\text { more enthusiastic in } \\
\text { king on the problems. The } \\
\text { ool has fulfilled all the } \\
\text { direments to carry out the } \\
\mathrm{m} \text { using Edubox, but there is a } \\
\text { e signal interference that is } \\
\text { less stable when the online } \\
\mathrm{m} \text {. And the exam using } \\
\text { box is fairly fast or more } \\
\text { ctive }\end{array}$ & $\begin{array}{l}\text { The existence of Edubox has very } \\
\text { good benefits including being } \\
\text { able to assist Educators in } \\
\text { completing the task of evaluating } \\
\text { social studies learning to be more } \\
\text { effective and efficient again and } \\
\text { being able to motivate to students } \\
\text { to be more enthusiastic in } \\
\text { working on exam questions. But } \\
\text { there are still obstacles in the } \\
\text { form of network interference }\end{array}$ & $\begin{array}{l}\text { In SMP Negeri } 10 \text { the existence of } \\
\text { Edubox is very helpful for Educators, } \\
\text { and can have a good impact as well } \\
\text { as the performance of Educators } \\
\text { being better than usual. Because with } \\
\text { this it can make educators become } \\
\text { more actively involved in the } \\
\text { implementation of exams through } \\
\text { Edubox. In terms of supporting } \\
\text { facilities Edubox can be quite } \\
\text { adequate }\end{array}$ \\
\hline
\end{tabular}

(Source: Data Processed by Researchers, 2019) 
Edubox can support the overall evaluation process of social studies learning in SMP 10 Bandung, Edubox supports facilities that are quite adequate. As well as being able to increase the active role of both educators and students in terms of participating in the implementation of Edubox-based exams such as, increasing the expertise of educators in the field of technology and through the attractive appearance. Edubox makes students more motivated to work on social studies exam questions. Likewise from the opinions expressed by Pranoto et al about the benefits of e-learning and L.Tjokro about the advantages of e-learning proved to be following what is in the field.

\section{b. Social Studies Outcomes of Affective Domains of Students Using Edubox in SMP Negeri 10 Bandung}

From the process of triangulation of information sources, it can be concluded that after the use of Edubox in SMP Negeri 10 Bandung, especially in class VII, it has a positive impact on the affective domain which, according to Andersen (in Amirono and Daryanto, 2016:32) this affective domain is divided into attitudes, self- concept and also interest. This is in accordance with what was discovered by researchers in the field that the affective domain of learning outcomes that can be known from the use of Edubox is able to shape students' attitudes to be more honest, self-concept here is able to train students to become independent learning terms of learning of course and in terms of interests here able to build a sense of enthusiasm and interest and comfort for students in the implementation of the exam, without having to be followed by fear in working on exam questions.

From the results of triangulation of data collection techniques that the social studies learning outcomes of the affective domain of students after using Edubox as seen from the results of interviews, observations and documentation studies explained there were no suspicious things or behaviors or negative actions that were shown by students when the process of examinations using Edubox So, it can be concluded that the existence of Edubox is able to provide good influence for students in the affective domain which can be seen from the attitudes, interests and self-concepts of students that lead to positive things.

Table 2. Social Studies Outcomes of Students Affective Domains After Using Edubox in SMP 10 Bandung

\begin{tabular}{|c|c|c|}
\hline $\begin{array}{l}\text { Grade VII students of SMP } \\
\text { Negeri } 10 \text { Bandung }\end{array}$ & Social Studies Educator & $\begin{array}{l}\text { Deputy head of school facilities and } \\
\text { infrastructure in the field of } \\
\text { management of Edubox }\end{array}$ \\
\hline $\begin{array}{l}\text { The existence of Edubox in } \\
\text { SMP Negeri } 10 \text { Bandung can } \\
\text { give effects and effects that } \\
\text { are very good for students that } \\
\text { is not easy to do cheating } \\
\text { when exams and this makes } \\
\text { students more honest and form } \\
\text { a good self-character. }\end{array}$ & $\begin{array}{l}\text { After using Edubox as an } \\
\text { evaluation tool for social studies } \\
\text { learning outcomes, it can be seen } \\
\text { that there are changes felt by } \\
\text { educators towards grade VII } \\
\text { students as well as being smarter } \\
\text { in dealing with time or discipline } \\
\text { and being able to shape the } \\
\text { character of honest students. }\end{array}$ & $\begin{array}{l}\text { Overall the existence of Edubox has a } \\
\text { good impact and effect for educators } \\
\text { and students of SMPN } 10 \text { such as the } \\
\text { attitude of Educators becoming more } \\
\text { active in the process of evaluating } \\
\text { social studies learning and with a } \\
\text { good Edubox appearance easily and } \\
\text { practically making students more } \\
\text { interested and enthusiastic in terms of } \\
\text { conducting PTS exams or PAT. }\end{array}$ \\
\hline
\end{tabular}

(Source: Data Processed by Researchers, 2019)

\section{c. Social Studies Learning Outcomes of Cognitive Domains Students Before and After Using Edubox in SMP Negeri 10 Bandung}

According to Bloom (in Sudjana, 2005:22) argues that Cognitive learning outcomes are related to six aspects such as memory, understanding, application, analysis, synthesis, and evaluation. In this case following what will be discussed namely about Cognitive Learning Outcomes in the form of knowledge and evaluation as the table below that describes the average results of social studies in each class as a whole without using Edubox and those using Edubox: 
Table 3. Average Results of Class VII Social Cognitive Values Before and After Using Edubox

\begin{tabular}{llcc}
\hline No & Class & Before & After \\
\hline 1. & VII-A & 66,46 & 80,62 \\
2. & VII-B & 67,87 & 77,12 \\
3. & VII-C & 68,68 & 76,62 \\
4. & VII-D & 71,90 & 79,72 \\
5. & VII-E & 71,03 & 77,22 \\
6. & VII-F & 70,18 & 77,66 \\
7. & VII-G & 72,12 & 75,74 \\
\hline \multicolumn{2}{l}{ Average Value } & 69,74 & 77,81 \\
Class & & \\
\hline
\end{tabular}

(Source: Data Processed by Researchers, 2019)

Based on the data above about the average results of IPS scores in each class VII, it can be said that there is indeed an increase in the value of those before using Edubox and after using Edubox as many as 8.07 scores on average scores. This increase occurs because of some internal factors that affect student learning outcomes, as expressed by Muhibbin (2010, p. 128), internal factors are factors that originate from within learners including psychological factors from intelligence, attention, interest, talent, motivation, and readiness of students when working on social studies learning evaluation tests using Edubox.

Table 4. Learning Outcomes of Cognitive Domains of Students Before and After Using Edubox

(Source: Data Processed by Researchers, 2019)

\begin{tabular}{ccccc}
\hline No. & Name & Class & $\begin{array}{c}\text { Conven } \\
\text { tional } \\
\text { Results }\end{array}$ & $\begin{array}{c}\text { Edubox } \\
\text { Result }\end{array}$ \\
\hline 1. & AP & VII-A & 73 & 72 \\
2. & AS & VII-B & 70 & 84 \\
3. & AM & VII-C & 66 & 74 \\
4. & RZ & VII-D & 83 & 88 \\
5. & MP & VII-E & 71 & 86 \\
6. & MD & VII-F & 63 & 78 \\
7. & MI & VII-G & 75 & 80 \\
\hline
\end{tabular}

Furthermore, based on the table above that explains the data values from the research informants as many as seven students in each class, each has one person, two values are obtained, each taken from different conditions from the evaluation in the form of conventional tests and also through the Edubox online evaluation tool.

The results of the test scores taken by the seven students almost overall experienced an increase from the conventional test tests with tests using Edubox, of course this has a very positive impact on learning outcomes of students in the cognitive domain in the form of PTS / PAT knowledge values.

The results of this study are also supported by previous research conducted by Gema Milda Hidayati (2016) which found that the use of ELearning as a tool for evaluating learning was able to influence the learning outcomes of students in the cognitive domain with an increase in the value of knowledge.

\section{CONCLUSION}

First, the overall response of students, educators or the school to the existence of Edubox is very good, being able to help all matters regarding evaluation held at school. In the process of conducting the exam, Edubox can support the continuity of the examination process. With adequate facilities able to provide benefits both for educators or students to better understand technology and facilitate educators in giving questions to students, with a simple and practical appearance that can facilitate students in working on the questions without having to provide other writing tools. And most importantly the existence of Edubox makes the implementation of learning evaluation more effective and efficient which is seen based on the performance of educators and students and accelerates the examination of evaluation values.

Second, there are some things that are felt both for educators and students after using Edubox as an evaluation tool for social studies learning outcomes that can be seen through changes in the effective domain consisting of attitudes shown by students that changes occur after using Edubox that is becoming more honest in exam work and be able to shape the character of the self to be even better to lead to the formation of a positive attitude. Furthermore, in terms of interest, the existence of Edubox with a good can foster a sense of interest of students to be more eager in working on the test seriously. And the last seen in terms of self-concept makes students become independent learning following the abilities they have. 
Third, cognitive learning outcomes can be categorized into grades obtained by students while undergoing the test using Edubox it can be said that most students experience an increase in social studies scores in each class compared to when the test uses conventional tests. This increase certainly has a good impact on students so that they can excel at school and able to participate in the current digital era.

\section{REFERENCES}

Alonso, F., López, G., Manrique, D., \& Viñes, J. M. (2005). An instructional model for webbased e-learning education with a blended learning process Approach. British Journal of educational technology, 2, 217-235.

Amirono dan Daryanto. (2016). Evaluasi dan Penliaian Pembelajaran Kurikulum 2013. Yogyakarta:Gava Media.

Anderson, N.F.W. dkk. (2017). Kerangka Landasan Untuk Pembelajaran Pengajaran dan Asesmen, Terjemahan Agung Prihantono. Yogyakarta: Pustaka Pelajar.

Bullen, M. (2001). E-Learning and the Internationalization Education. Malaysia Journal of Educational Technology, 1, 3746.

Chandrawati, Sri Rahayu. (2010). Pemanfaatan E-learning dalam Pembelajaran. Jurnal Untan: 8(2).

Darmawan, Deni. (2014). Pengembangan ELearning Teori dan Desain. Bandung: PT Remaja Rosdakarya.

Effendi, R dan Sukmayadi, V. (2017). Communication and Students' Needs Measuring Students' Affect toward Teaching and Learning Process in Higher Education. The 2nd International Conference on Sociolgy Education, 511515.
Haughey, M. \& Anderson, T. (1998). Elearning in the 21 century. A Framework for research and practice. New York: Routledge Falmer. Netwokerd Learning: The pedagogy.

Info Bandung. (2018). Pengembangan Edubox. Diakses dari: https://infobandung.co.id/inifungsi-dari-edubox-smart-schoolyang-diluncurkan-di-kota-bandung

L. Tjokro, Sutanto. (2009). Presentasiyang Mencekam. Jakarta: Alex Media Komputindo.

Peraturan Pemerintah Republik Indonesia Nomor 32 Tahun 2013 Tentang Perubahan Atas Peraturan Pemerintahan Nomor 19 Tahun 2005 Tentang Standar Nasional Pendidikan, Kompetensi Inti Pasal 77C.

Pranoto, Alvini.dkk. (2009). Sains dan Teknologi. Jakarta: PT Gramedia Pustaka Utama.

Purwanto. (2011). Evaluasi Hasil Belajar. Yogyakarta: Pustaka Pelajar.

Rusman. (2013). Model-Model Pembelajaran: mengembangkan Profesionalisme Guru. Jakarta: PT Raja Grafindo Persada.

S.Eko Widiyoko. (2009). Evaluasi Program Pembelajaran. Yogyakarta: Pustaka Belajar.

Sapriya. (2015). Pendidikan IPS.Bandung: Remaja Rosdakarya.

Sudjana, Nana. (2009). Penilaian Hasil Belajar Mengajar. Bandung: PT. Remaja Rosdakarya

Sudjana, Nana. (2005). Dasar-dasar Proses Belajar Mengajar. Bandung: PT. Remaja Rosdakarya

Syah, Muhibbin. (2010). Psikologi Pendidikan dengan Pendekatan Baru. Bandung: Remaja Rosdakarya. 